\title{
Problems and Discussion of Aesthetic Education in Colleges and Universities
}

\author{
Ge Bai \\ School of Architecture and Urban Planning \\ Huazhong University of Science and Technology \\ Wuhan, China
}

\begin{abstract}
Aesthetic education is a major part of higher education, and is one of the important means for colleges and universities to cultivate students. One of the main problems faced by colleges and universities in the 21st century is how to build an art education system represented by humanities and arts in colleges and universities to make regular higher education become a true "beauty" education, and is also an important aspect of measuring the overall strength of a university. Art education in colleges and universities is a major part of aesthetic education in colleges and universities, and the quality of art education directly affects the development of quality education in universities. This paper starts with the origin of aesthetic theory, analyzes the problems existing in the current art education in colleges and universities, and proposes some corresponding countermeasures by reflecting on the problems of the arts.
\end{abstract}

Keywords-colleges and universities; educational reform; aesthetic education

\section{INTRODUCTION}

The ancient and modern educators, philosophers and educational institutions have all attached great importance to the study of aesthetics. Confucius, an ancient Chinese educator, places the "music", one of the "Six Arts", in the second place. The "music" refers to a comprehensive education subject that integrates dance, music, art and literature. Confucius advocates that "ritual" and "music" should be of equal importance, and the combination of various forms of art can improve people's aesthetic ability, adjust temperament, and imperceptibly influence the social morality. [1] Mr. Cai Yuanpei has also proposed the concept of "substituting aesthetic education for religion". From that time, Peking University was full of humanistic feelings. Its concept of attaching importance to art education has been still in use today, which is of great significance to all universities in China and promotes the development of Chinese aesthetics education.

\author{
Yujie Lu \\ School of Architecture and Urban Planning \\ Huazhong University of Science and Technology \\ Wuhan, China
}

\section{The PREDICAMENT OF ChINESE AESTHETIC EDUCATION}

A. The Teaching Quality of Aesthetics Course Is Not High and the Course Deviates from the Contemporary Art, and the Teaching Is Not Standardized and Lacks Culture

Aesthetic education often comes from art teaching. In terms of art education classes, although it has entered various colleges and universities, its development still stays in an imbalanced and incomplete situation. The number of aesthetic education courses offered by contemporary universities varies, and the quality of teaching is also different. The reasons are closely related to the importance of university for aesthetic education. For many non-art majors, the most opportunities to contact with aesthetics and art should be in public elective courses offered by universities. However, as far as public electives are concerned, a large part of aesthetics-related courses are directly copied from the courses of art departments. Some students who have little or no contact with art aesthetics have some difficulties in learning, and the original purpose of teaching according to one's ability has not been taken into account. In this way, students will only pursue the score blindly, so that the original imaginative aesthetic education will become mechanized.

With the fast-changing contemporary art, new aesthetic works and aesthetic concepts have emerged in endlessly. As university teachers, they are more obliged to take the initiative to contact these new things. However, some teachers still "sticks to the old path" or "are satisfied with the present and will not strive for the better". They are prejudiced against or reject new things, are confined to a narrow idea, and do not allow aesthetic thought to play a real role. As a result, the education concept of the university will gradually deviate from the diverse arts and culture of the society, which will create estrangement. Teachers should teach students the aesthetic concept and aesthetic vision rather than specific art techniques in contemporary universities. Aesthetic learning is different from science and engineering majors, and it requires more sensibility rather than rationality. Marx once said that the development of human creativity, opposites, and diversity is humanized and consistent with them. Aesthetic learning is a process of romance, pleasure, full of variables or uncertainty. Teachers should encourage students to discover the special value of themselves, and encourage the importance of multiple 
aesthetics. Perhaps part of contemporary education gradually transforms students into individuals without personality, and they cannot accept diversified beauty and diversified culture, so it is hard for them to learn the merits from the new aesthetic ideas. There is a touch of aesthetic fascism. At present, many art teachers have graduated from the relevant academy of arts. They inevitably lacks teaching experience due to young age and junior qualification, and their teaching puts more emphasis on techniques rather than aesthetics. Some of teachers have graduated from art universities with solid professional knowledge but scarce cultural heritage, and they are prone to irregular teaching in the course of teaching. As a result, it is difficult to arouse the interest of students, and the overall development and promotion of aesthetic education courses will also be affected.

\section{B. The Art Activity Gradually Separates from the Original Intention of "Universal Type" and Aesthetic Education Lacks System Safeguard and Policy Support}

The cultivation of artistic accomplishment cannot be separated from art education. Therefore, for the students not majoring in art, except the general course of arts, colleges usually encourage students to develop art club, comprehensive art activities and so on. Due to the displaying features of this activity, after professional and theoretical study, students majoring in art often well grasp the aesthetic concept and have faster receptivity in the activities than other majors. In the achievement exhibition, some colleges usually pay more attention to the students in art major, or even only accept them in recruiting organization members. In this way, it deviates from the original intention of "universality" and "generality" of aesthetic education.[2] Aesthetic thoughts come from art education activities, which are also the significant constituent parts of spiritual civilization of colleges. When this kind of art activity is isolated by students in art major, it will separate the essence of aesthetics civilization from the public.[3] However, aesthetic education is not the "highbrow art and literature", on the country, it belongs to "popular literature". At present, colleges do not put more emphasis on aesthetic education, if any, the concerns are only embodied in word and on the surface, and they lack corresponding measures. The art education activity center or cultural and educational activity center established by some colleges and universities are often affiliated to other schools, such as school of art and faculty of humanities. Therefore, the autonomous rights of activity center are lost. For example, the limits of powers, such as personnel, teaching management, property and art direction, are greatly affected. In this way, many aspects, such as professional title, assessment, project application, discipline development plan and so on, are influenced by the higher-level unit, therefore, it often stays at a disadvantage. Due to the unsound organization and lack of system safeguard, the achievements of teachers are difficult to be recognized or rewarded, and the enthusiasm of teachers will be greatly reduced. With various types of projects, the institutional order will not be smooth and the entire system will enter into a vicious cycle.

\section{The Concept of Exam-oriented Education Is Strong, the Aesthetic Education Lacks Humanistic Feelings and Doesn't Pay Attention to "People Oriented" Thinking}

Affected by the traditional education theory system, aesthetic education is usually used as an appendage to the whole teaching structure, and cannot be fully emphasized in the overall teaching. Teachers do not pay attention to, so it is hard for students to fully understand the importance of aesthetics. Meanwhile, aesthetic teaching and art education in a certain situation will be regarded as the "shortcut" under the pressure of high employment environment in certain situations. At present, for the vast majority of art students, most of them have studied art for the examination, but students who love art and are willing to learn more about it are in the minority. According to this situation, some art studios and art institutions have made education more test-oriented, and they set the pattern and students only need to follow it. Such stereotyped works of art lack self-aesthetic taste and personal characteristics. This has more or less affected the current university teaching. Influenced by the tide of traditional theory, the original aesthetic freedom is limited, and the entire teaching model has become rigid. The conceptual problem is difficult to change. Affected by social utilitarianism, schools are more willing to teach pragmatic skills than aesthetic ways, which is not conducive to the development of students' personal qualities and aesthetic tastes.

\section{Blindly Worshiping Foreign Things and Lacking Self- cultural Value Identity}

Today, China's aesthetic education has not formed a system. We often take the western aesthetic as the target model, but lack the self-examination and transformation. In the process of art modernization in China, its ideas and ways often reflect western characteristics. Countries often borrow from each other's modernization experience in the political system, economic system and science and technology system. In terms of the "modernization" of art culture, countries face the difficult choices between modernity and tradition, and they also seem to be confronted with the problems of westernization and nationalization. [4] At the present stage, some students often blindly pursue westernized aesthetics while ignoring the inheritance of traditional Chinese aesthetics. As a student in twenty-first century, they should pursue their own cultural value identity. The blind pursuit of westernization may make their value judgment more confusing when students haven't found their own aesthetic value orientation. The freedom and openness brought by western modernization are of reference for us, but at the same time it also brings with us the difficulties of self-recognition and the loss of sense of cultural value belonging. Similarly, some art universities and departments only pay attention to making students learn the techniques of western painting. Their basic way of learning art is to imitate its style and pattern, which will only form a mechanical and orderly painting habit, and also make students deviate from the objects to create arts; therefore, it often becomes the common failing of students in art major. This learning method that "imitate west style" will not enable students to fully understand the true connotation of aesthetic education, on the contrary, it will lead to a situation of similar creative methods and lack of imagination. 


\section{REFLECTION ON THE REFORM OF CHINA'S AESTHETIC EDUCATION}

\section{A. Changing the Status Quo Based on Pragmatism Improving the Humanism of Art Education and Cultivating the Aesthetics Capacity}

We often encounter such situation: no matter how interested we are in this course, but if teachers do not pay attention to it, our interests will be greatly reduced. In contemporary university education, aesthetics seems to be the appendage of the whole teaching, in terms of aesthetic education, and there are some problems in our understanding on it. Under the predominance of pragmatism, some university leaders do not pay much attention to aesthetic education, which will lead to a series of problems, such as unsound education institutions, difficulties in implementing various subjects, and the lack of high level of teachers. [5]

In ordinary universities, we need to cultivate the construction talents with artistic quality. If we really want to play a role in the comprehensive quality of college students and the cultivation of their creative thinking, we should mainly improve the quality of the whole faculty, which includes various aspects: aesthetics quality, aesthetics ability, cultural quality, and so on. After all, the lecturer is a teacher, and only the enthusiasm of teachers is improved and teacher can pay more attention to the course, and the whole aesthetic teaching concept will naturally develop towards the "humanity". It is also important to actively build the related courses of public art. The Guiding Plan for Public Art Courses in National Colleges and Universities has pointed out that "the public art course is a limited elective course designed to cultivate the high-quality talents required by socialist modernization, which has an irreplaceable role in improving aesthetic qualities, cultivating innovative spirit and practical ability, and shaping a sound personality." Through some general courses, we will gradually reverse the misunderstanding of the "practicability" of aesthetic education, so that aesthetic education can be more 'people-oriented".

\section{B. Popularizing Aesthetic Education and Perfecting Guarantee System}

Aesthetics course and art activities are a interactive process. Aesthetics course education provides theoretical guidance for the development of artistic activities, and we should cultivate students' aesthetic and cultural heritage and build their cultural self-confidence. Art activities also react on the aesthetics course, and students can further improve their aesthetics theory by practice. The two develop mutually in the process of continuous interaction. Aesthetics education courses are limited in time and space, so universities can encourage the development of such arts club activities, and provide hardware facilities including sites and equipment facilities. Actively conducting arts and aesthetics education activities will also play a catalytic role in building general education. Even if the students cannot fully get the cultivation of aesthetic skills, they can be influenced by what they constantly see and hear and nurtured, which has a significant effect on cultivating the spiritual civilization of contemporary college students. Many art activity centers are affected by subordinate and attached units, and are often at a disadvantage. Therefore, in order to solve such problems, the status of these art institutions should be promoted and their ideological understanding should be fully enhanced. These public arts education centers or institutions set up in colleges and universities should improve corresponding systems in division of responsibilities, development orientation, and corresponding policies.

\section{Reasonably Setting up Courses to Integrate Major and Art}

Because of low correlation with their own major, there is a bias for non-art students to understand the course if they directly study the courses related to art majors. In the framework of the whole education system, science education, humanities education and art aesthetics education should be intersected and interacted. [6] We should develop aesthetic education that is relevant to our own profession. For example, students of science and engineering colleges can integrate aesthetic education with science and engineering professional education on the basis of learning aesthetics, basic knowledge of art, teaching of skills, and aesthetic appreciation. We should convert the courses from art theory to a integration of art and science and engineering, such as "Science and Aesthetics" "Mathematics and Art", and so on. As a result, students have high acceptability and enthusiasm in this course. It is also a powerful booster for the entire teaching model, increases the enthusiasm of the teachers, and also plays a positive role in the teaching process.

With the improvement of the economic development level, we should rationally plan the development of art popularization education. On this basis, we further deepen the education of the art major, make the art popularization education and the art major education complement each other and develop together, so as to jointly create correct aesthetic value orientation for college students. At present, some teachers are engaged in the work of art popularization, but the speed of knowledge change is relatively fast, therefore, their rights cannot be guaranteed and status is difficult to improved, and they rarely feel the achievements in working [7] Therefore, even if colleges and universities want to vigorously promote art popularization education, they also should attach importance to the professional knowledge, so that related art research can be improved. Broadening the professional categories of various disciplines in the university can also promote the education of art popularization. This can not only facilitate the long-term development of art education, but also enable the students to be subtly influenced in the artistic atmosphere of the campus; therefore, students can get the edification gradually to improve their cultural deposits and aesthetic emotion.

\section{Improving the Understanding of Chinese Aesthetics and Enhancing the Awareness of Culture as the Theme}

The construction of aesthetic teaching mode in China should not only just put emphasis on the concept "peopleoriented", but also concentrate on the style of "Chinese aesthetics". In the process of learning good foreign ideas, we should also stand firmly on our country's aesthetics, and show self-value in the form of self-determination. In accordance with the requirements of the western aesthetic realistic 
modeling, the depth of realism and depiction often becomes the decisive factor in judging ability in contemporary Chinese painting teaching style. This kind of paradigm-based teaching model is increasingly solidified, and there are very few parts that are really used for creation. From this point of view, excessively sticking to rigid western model sometimes becomes a fetter to develop the national aesthetics education, impeding the development of the spirit of freedom. Representing the content of Chinese aesthetics is not merely the category of Chinese painting, but also aesthetic thinking from the cultural level, therefore, it can represent the important content of national culture, which equates to the traditional literature, history \& philosophy.[8] The value of Chinese aesthetics has passed through several years, and undergone countless creative changes. It represents the cultural differences and aesthetic concepts in different ages, different regions, and different groups of people, and is deeply branded with the characteristics of the Chinese era, which is the superiority that other cultures cannot be changed and compared. In contemporary, the aesthetic education in China should also be activated and adjusted along with the change of era. China's aesthetic education should deliver China's own aesthetic values and should not stick to specific limitations. The aesthetic courses of various colleges and universities also need the support of rich cultural heritage of Chinese aesthetics, so as to build students' cultural awakening and self-confidence based on this, constantly bring forth new ideas, continue to innovate, and make the Chinese aesthetic education generate new luster.

\section{CONCLUSION}

With the continuous deepening of China's education reform, education reform has been given high priority, and aesthetic education should also exert its true value. Today, aesthetic education should pay attention to the concept of people first, take full consideration to the teaching practice, actively intersect with the related major, change the concept of "pragmatism", vigorously develop the Chinese aesthetic concept, and fully reflect our own cultural confidence. The ultimate goal of aesthetic education is to improve students' artistic quality and aesthetic ability, so as to cultivate positive and healthy aesthetic appreciation ability and to further cultivate sound personality and comprehensive quality. In the meantime, colleges and universities should also pay attention to art general education during the implementation of aesthetic education, so that aesthetic education can become a powerful link in quality education of colleges and universities. It is just around the corner for China to cultivate high-quality, comprehensive, and innovative talents.

\section{REFERENCES}

[1] Huang Changhai. Practical role and significance of art education in colleges and universities [N]. Journal of Southeast University (Philosophy and Social Science), 2007. 5. 黄昌海. 充分认识艺术教育 在普通高校中的现实作用与深远意义 $[\mathrm{N}]$. 东南大学学报(哲学社会科 学版), 2007.5.

[2] Pang Haishao. The Predicament and Way Out of Public Art Education in University [J]. China Higher Education Research, 2005(12): 77-78.
庞海苻. 大学公共艺术教育面临的困境和出路[J].中国高教研究, 2005 (12):77-78.

[3] Bie Dunrong, Xia Jin. On Professionalization of Art Education and Its General Feature [J]. Journal of Higher Education, 2013.2 (2): 60-66. 别 敦荣, 夏晋. 论艺术教育的专业化及其通识性 [J]. 高等教育研究, 2013.2 (2):60-66.

[4] Wu Xiaochuan. Loss and Remodeling - Thinking and Research on Constructing the Teaching Mode of Contemporary Chinese Fine Arts Education [D]. Xi'an: Xi'an Academy of Fine Arts, 2013. 武小川.迷失 与重塑一一构建中国当代美术教育教学模式的思考和研究 $[D]$.西 安: 西安美术学院, 2013

[5] Fan Zhonghong. College of Arts Education Status Quo and Countermeasures [J]. Hebei Academic Journal, 2009.3 (2): 250-252. 森 中红.普通高校艺术教育的现状与对策研究 [J]. 河北学刊, 2009.3 (2) :250-252

[6] Zhu Jinxiu, Luo Xiaohuan. On the New Direction of Art Education in China - Thoughts on the Art Education Path after Art Theory Become a Category [J]. China University Teaching, 2013 (5): 40-42. 朱锦秀,罗晓 欢. 试论我国艺术教育的新向度一一艺术学成为门类后的艺术教育 路径之思考[J]. 中国大学教学,2013（5）:40-42.

[7] Ju Xiangling, He Xiumei. How Far Is Art Education from Us? Analysis of the Status Quo of Public Art Education in Colleges and Universities and Discussion on Its Value [J]. Art Education, 2012.8: 613. 鞠向玲,贺秀梅. 艺术教育离我们有多远? - - 高校公共艺术教育 现状分析及价值探讨 [J].艺术教育，2012.8：6-13.

[8] Xu Lei. Towards Integration: An Effective Approach to Construct Curriculum of Public Art Education in Colleges and Universities [N]. Journal of Xinjiang Education Institute, 2009.6. 许蕾.走向综合化的艺 术教育——普通高校公共艺术教育课程建构的有效途径 [N].新疆教 育学院学报, 2009.6. 